\title{
The role of medical students in active search of transfusional incidents
}

O papel do estudante de medicina na busca ativa de incidentes transfusionais

Rodolfo Daniel de Almeida Soares, Daniel Soares Serafim, Emanuel Lucas de Sousa Leite, Francisco Ademar Fernandes Junior, Gabriella Leonardo Oliveira Caldas, Isabella Karen Freitas Rabello, Karla Cristina Franco Guimarães Nunes, Lorena Caroline Vieira Barbosa, Manassés Medeiros Alves de Araújo

Study performed at Department of Clinical Medicine, Federal University of Rio Grande do Norte (UFRN), Brazil.

Financial support: Extension of the Federal University of Rio Grande do Norte. PROEX: PJ707-2016.

Conflict of interest: None.

Correspondence address: Rodolfo Daniel de Almeida Soares; Departament of Clinical Medicine, Federal University of Rio Grande do Norte (UFRN), Brazil. Avenida Nilo Peçanha, 620, Petrópolis, Natal-RN, Brazil. Email: rodolfo.ufrn@gmail.com

Submitted: November 10, 2016. Accepted, after review: December 12, 2016.

\begin{abstract}
Purpose: The aim of this study was to report medical students' experience in hemovigilance through the active search of transfusion incidents. Methods: The study was done from January of 2013 to January 2016, at a university hospital. There were daily visits to all patients who had been transfused at least one blood component at this hospital, by using questionnaires about these transfusions. Transfusion incidents were identified, the cases were notified and passed on to doctors in order to confirm the adverse event. We analyzed, through active search, 12552 blood transfusions in 4255 transfused patients during the collection period. The average number of patients evaluated per student was 472 patients. Through hemotherapic and clinical knowledge, 67 transfusion incidents were identified, notified and confirmed, corresponding toan average of 7,44 per student. Knowing common aspects of blood transfusions and adverse events, as well as their prevention, allows safer hemotherapic technics. Conclusion: The present initiative improved doctor-patient relationship of the students, through daily contact and development of humanizing and ethics technics. It also enabled practical transfusional experience, contributing to an integral formation of the students.
\end{abstract}

Keywords: Transfusion. Hemotherapy Service. Blood Transfusion. Education, Medical. Students, Medical. Physician-Patient Relations. 


\section{RESUMO}

Objetivo: Relatar a experiência de graduandos de medicina na hemovigilância hospitalar através da busca ativa de incidentes transfusionais imediatos. Métodos: O estudo foi realizado no período de janeiro de 2013 a janeiro de 2016 em um hospital universitário. Foram realizadas visitas diárias a todos os pacientes que receberam transfusão de hemoderivados com pelo menos um hemocomponente nesse hospital e questionamentos sobre essas transfusões. Os incidentes transfusionais eram identificados, notificados e repassados aos médicos responsáveis para confirmação da ocorrência. Foram analisadas, através da busca ativa, 12.552 transfusões sanguíneas e 4.255 pacientes foram visitados. Cada estudante avaliou, em média, a transfusão de 472 pacientes. Através do conhecimento hemoterápico e clínico, 67 incidentes transfusionais foram identificados, notificados e confirmados, correspondendo a uma média de 7,44 incidentes identificados por cada estudante. Conhecer aspectos comuns das transfusões, eventos adversos e sua prevenção possibilita práticas hemoterápicas mais seguras. Conclusão: Dessa forma, a presente iniciativa auxiliou o aperfeiçoamento da relação médico-paciente dos estudantes, através do contato diário e do desenvolvimento de condutas humanizadoras e éticas com o paciente, além de possibilitar a vivência na prática transfusional, contribuindo, assim, para uma formação integral dos graduandos.

Descritores: Medicina Transfusional; Serviço de Hemoterapia; Transfusão Sanguínea; Educação Médica; Estudantes de Medicina; Relações MédicoPaciente.

\section{INTRODUCTION}

Blood transfusion is an effective way of re-establish a patient's clinic condition, however, it is also a costly treatment for the Brazilian healthcare system (SUS). Even though its use within the boundaries of established norms, the treatment still incurs several risks ${ }^{1}$. For security's sake, hemovigilance is necessary. Its network oversees the receptors epidemiological surveillance of donors and of eventual transfusional incidents $(\mathrm{Tls})^{2}$. Therefore, hemovigilance presents itself as a system of evaluation and alert that aims to apply corrective and preventative measures that contribute to transfusional security.

In order to grant an effective functioning of the network monitoring, the system must be integrated, continuous and standardised throughout its whole 
process. Thus, the active collaboration of all the involved professionals is of the utmost importance, because the identification and notification of Tls stand as a final course of action, enabling the detection of problems in all the stages beforehand, enabling also corrective measures ${ }^{3}$.

With this in mind, since 2002 Tls notification has become mandatory. However, only $10 \%$ of the TIs are truly notified ${ }^{4}$. Despite this fact, several studies stress the importance of monitoring the reaction of patients in healthcare services ${ }^{5,6}$.

The detection routins of Tls within hospitals is usually restricted to the medical and nursery teams, thus forcing transfusional protocols to be reduced to the prescribing and resolving adverse transfusional events. The literature, however, stresses the need for improving transfusional knowledge by medical professionals as a whole, seeing that its proper usage incurs measures that involve far less risks and mitigate costs to entities responsible for hospital administration?

International programs have been developed with the attempt to promote the teaching and research linked to transfusional medical practises and are showing satisfying results ${ }^{8}$. In Brazil, a possible solution is based on the inclusion of other people, such as medical students and healthcare administrators, in hemotherapic practises, thus improving the knowledge and strengthening transfusional committees, through the disclosing of hemotherapic practises to society and training programs for healthcare students ${ }^{9}$.

Medical students, in their learning process and as healthcare professional prospects, have been dealing with different realities that coalesce into knowledge for their future actions as full-fledged professionals ${ }^{10}$. Therefore, their inclusion into ITs active searches, through daily visits, makes these students learn about transfusional therapeutic routines, such as the relationship between doctors and patients. This fact is explained by the individual contact with each patient who has undergone transfusional processes, by their questions about transfusional therapeutics and by the patient's health status in a general manner. With this, the students will be inserted into transfusional routines and the dealings with patients, 
thus improving their more humanist sides by strengthening bonds between doctors and patients ${ }^{11,12}$, and the student's knowledge about hemotherapy.

This paper aims to describe the experiences of medical undergraduation students of the Federal University of Rio Grande do Norte (UFRN) that are inserted into the project for active searches of transfusional incidents in the University Hospital Onofre Lopes (HUOL), in the city of Natal, Brazil.

\section{METHODS}

This paper is an experience report with describing methods about medical undergraduation students' experiences in active searches for TIs, from January 2013 to January 2016. Data was gathered by daily visits in the HUOL through the aforementioned period.

The University Hospital Onofre Lopes (HUOL) is located in the city of Natal, Brazil, and is a public institution, serving as teaching hospital, and performs tertiary treatments in medical clinic, surgery, paediatrics, hemodialysis, intensive care units (UTI), etc.

Nine undergraduation students that belonged to the $12^{\text {th }}, 8^{\text {th }}, 7^{\text {th }}$ and $5^{\text {th }}$ terms of the UFRN's medical school course were selected based on their own interests in hemotherapy, as well as their participation in projects in the area. The HUOL blood bank (BS) and its other sectors were also selected as fields for the current analysis.

In a daily basis, one student visited the blood bank in order to collect information from the transfusions made in the last 24 hours by looking at the internal requisitions logs of the hospital. With this information in hand, the students proceeded to list the patients that received blood, the hemocomponents, blood type and Rh factor, amount of bags, date and time of each bag's installation and the sector where the hemotransfusion took place.

From this list, the student, then, analysed the patient's records and interviewed them, along with physical examination, in an attempt to evaluate if the patient bore signs and symptoms related to an $\mathrm{TI}$ scenario. When there was a possibility of an $\mathrm{TI}$ presence, the student collected more information that would 
help in better knowing the individual and pinpoint factors that contribute in the establishing of a profile of patients that have shown adverse ITs, thus allowing a broader perspective on the factors that may have caused the incidents. In the end, the following data was gleaned: epidemiological data of the patient's base pathology, transfusional indication and procedures' descriptions (medical measures adopted in order to reverse the TI). In this process, skills such as conducting anamnesis, evaluation and hemotherapic indication protocol.

After this set of procedures, the patient was oriented about signs and symptoms that may surface, as well as the need to communicate anything related to their disease to the assisting healthcare team, so that no TI go unnotified and adequate treatments may be administered properly. The assisting healthcare team or the team on duty was also oriented on the recognising and notification of TIs.

Spreadsheets were made to gather general data and the results, thus enabling a clearer analysis about the ITs and transfusional data. This analysis was made through simple distributions, such as average, frequency and percentage, obtaining thus conclusions about IT standards observed at the HUOL.

In possession of all transfusional data, in a monthly basis, the haematologist doctors team's meeting was held aiming to discuss the notified cases, with a presentation of the patient's clinical status, reports from the assisting healthcare team about the case and the explanation of the interview with the patient. Afterwards, an agreement was reached about the IT legitimacy and its classification regarding gravity levels, timing and reactive type. Additionally, more measures were discussed in order to improve the hospital's hemovigilance system and awareness methods of hemocomponents usage by the medical team.

\section{RESULTS AND DISCUSSIONS}

We analysed 12552 blood transfusions in 4255 patients during the study period. Each student visited an average of 472 patients. The amount of transfused hemocomponents and blood transfusion sectors are shown in Table 1. 
The role of medical students in active search of transfusional incidents

Soares, RDA; et al

Table 1 - Blood transfusions per hospital sectors quantity

\begin{tabular}{lc}
\hline \multicolumn{1}{c}{ Sector } & Blood Transfusions \\
\hline Infirmary & 5966 \\
Intensive Care Unit & 4279 \\
Surgical Center & 1471 \\
Haemodialysis & 836 \\
\hline Total & 12552 \\
\hline
\end{tabular}

Source: HUOL, 2013- jan/2016

Students identified fifty Tls, 98\% of which were confirmed. Two percent of the cases were considered inconclusive, due to lack of information required to precisely associate the incident to the transfused hemocomponent. Each student identified an average of 7,44 incidents. The frequency of Tls in the period between 2013 and 2016 remained at $5.3 \%$ per 1000 hemocomponents.

All the sectors were visited by the students, so that the latter had contact with different pathological situations that may require hemotherapic treatment. The main base diseases of patients that presented Tls are shown in Table 2.

Table 2 - Distribution of patients' base maladies that showed transfusional incidents

\begin{tabular}{lcc} 
Variables & N & Prevalence (\%) \\
\hline Oncological maladies & 20 & 29,96 \\
Genitourinary maladies & 8 & 11,92 \\
Hemathological maladies & 17 & 25,33 \\
Gastrointestinal maladies & 7 & 10,43 \\
Cardiovascular System maladies & 4 & 5,96 \\
Neurological maladies & 2 & 2,98 \\
Respiratory maladies & 1 & 1,49 \\
Rheumatologically maladies & 2 & 2,98 \\
Not informed & 6 & 8,95 \\
\hline Total & 67 & 100
\end{tabular}

Source: HUOL, 2013- jan/2016

Tls notified at $\mathrm{HUOL}$ (in a compulsory manner and via active search) in 2012, 2013, 2014, 2015 and in January 2016 corresponded, respectively, to 4 (3997 transfusions), 24 (4109 transfusions), 26 (4363 transfusions), 14 (4279 transfusions) and 3 (328 transfusions). Notifications registered in 2012 were made 
in compulsory manner only, and were sent to HUOL's Hemotherapy and Hemathology Center.

Active search for Tls performed by the joining scholars of hemovigilance at HUOL acquires a deeper importance in the process of medical studies, seeing that it allows for the developing of clinical abilities in the domains of hemathology and hemotherapy, especially concerning transfuisonal reactions. When there is a possibility of an $\mathrm{TI}$, the student turns to the diseased in order to confirm the former's suspects, asking the patient about clinical and epidemiologic aspects of the situation. From that point is developed the clinical chain of thought that will guid the decision of whether or not the event must be notified. Then begins the search for medical records, wherein the student intends to differentiate the reaction shown from another clinic manifestation, such as the worsening of the patient's base malady, reaction to the chosen treatment, or a clinical characteristic that was already existing, but was only noticed by the patient during hemotransfusion ${ }^{13}$.

After the confirmation of possible suspicions and the detection of the incident, there is the filling of the transfusional Incident ( $\mathrm{TI}$ ) form, the patient warns the assigned doctor of the case, and then the fact is presented to the hemovigilance project team. With this in mind, it can be inferred that several fundamental aspects are contemplated in order to achieve a good medical practise, since, despite being about ITs, the frequent contact with patients provided by hemovigilance gives a significant contribution for the improvement of general medic education. Aside from that, the transfusional reaction communication to the assigned doctor by the patient allows for an exchange of knowledge between professional and students, which will help students to build their relations and their rhetorical capacities to defend the existence of an incident ${ }^{14}$.

Additionally, the hemovigilance project bestows several opportunities to medical students to improve their interpersonal relations with patients and their companions. Such capacity will help them greatly in their future as healthcare professionals. During the course of the visit, the student stands close to the sickbeds, responsible for gathering relevant information and make the proper 
decisions. These opportunities are unique, as they allow the student to amplify their humanistic characteristics by hearing the patient's complaints, fears, and expectations. The dialogue with the patient and the dedication to them helps the student to strengthen bonds. This capacity is only achieved by true and absolute care with the patient, and the students will only live this after his/her undergraduation is properly finished, when in possession of their own patients ${ }^{15}$.

Another social skill developed by the student is the interaction with a multiprofessional team ${ }^{16}$, both the teams directly involved in hemovigilance, and the ones responsible with the patient. Once again the student sees him/herself responsible for making decisions, being able to establish effective communication forms that enable a proper performance ${ }^{17}$.

The teaching of hemotherapic practises is generally considered to be lacking in the Brazilian medical curriculum. The chance to insert oneself in hemotherapy processes generates knowledge about each ste in the chain of blood transfusion, transfusional vigilance, hemotherapy indication and its associated protocols, and turns possible the knowledge of adverse incidents linked to transfusion. One of the most effective ways to reduce the number of incidents related to blood transfusion is to use hemocomponents rationally. Knowledge acquired during students' insertion in this environment may help in this occasion $^{18,19}$.

In such manner, the active search of transfusional reactions enables the broadening of knowledge concerning hemotherapic conducts and the knowledge about transfusional reaction, as well as assisting in the building of a relationship between doctor and patient, thus improving the ethical and humanistic aspects. The active search also bestows knowledge concerning hemotherapy indications and adverse reactions, giving the patient a more secure footing, avoiding unnecessary transfusions. Additionally, such search also incurs a better assistance to the patient, diminishing the number of unnoticed notifications. More notified reactions translate into more information about the very core and factors involved in the reactions, as they feed the National Hemovigilance System and lead to more investigations on the subject, thus augmenting patient's security. 


\section{CONCLUSIONS}

The results of the current study show that the insertion of medical students in the active search of Tls and, consequently, in the hospital environment, allows for an improvement of their relationships with patients and their knowledge of transfusional therapeutics. Thus, it is relevant to incorporate students in the hemovigilance services in teaching hospitals throughout the country, in order to improve medical education.

It is suggested that the increase in number of students that seek to work with hemovigilance and their insertion into other hospital networks in the state will allows for a better watch for the transfusional chain process and better therapeutic options for receptors. Such course of action improves IT monitoring and the adoption of effective therapeutic measures to avoid placing the patient in risk. Additionally, this insertion allows an increase in the number of transfusional notifications, since the active search would be done on a daily basis.

It is expected that this paper provides clearer information for professionals that deal routinely with blood transfusion, as well as spur new ideas for the implementation of hemovigilance system in other hospitals, improving wholly transfusional security.

\section{REFERENCES}

1. Brasil. Ministério da Saúde. Secretaria de Atenção a Saúde. Departamento de Atenção especializada. Guia para o uso de hemocomponentes. Brasília: Editora do Ministério da Saúde, 2010.

2. Brasil. Ministério da Saúde. Agência Nacional de Vigilância Sanitária. Hemovigilância: manual técnico para investigação das reações transfusionais imediatas e tardias não infecciosas. Brasília: Anvisa, 2007.

3. Brasil. Agência Nacional de Vigilância Sanitária. Boletim de Hemovigilância no 5. 1.ed. Brasília, out. 2012.18p. [capturado em: 10 nov 2014]. Disponível em: http://www.portal.anvisa.gov.br/.

4. Brasil. Agência Nacional de Vigilância Sanitária. Relatório de Hemovigilância 2007 a 2013. Brasília, out. 2014.06 p. [capturado em: 25 ago 2015]. Disponível em: http://portal.anvisa.gov.br/wps/wcm/connect/85bb530046523334bf99ff419d65 ea09/Relatorio_Hemovigil_2007-2013.pdf?MOD=AJPERES.

5. Saito, M. Hemovigilância: Eventos transfusionais adversos antes e após implantação de um Comitê Transfusional Hospitalar. Londrina; 2010. Mestrado [Dissertação] - Universidade Estadual de Londrina.[capturado em: 
10 fev 2015]. Disponível em: http://www.uel.br/pos/saudecoletiva/Mestrado/diss/114.pdf.

6. Torella F, Haynes SL, Bennett J, Sewell D, McCollum CN. Can hospital transfusion committees change transfuse on practice? J Royal Soc Med. 2002; 95(9) 450-452.

7. Rock G, Berger R, Pinkerton P, Fernandes B. A pilot study to assess physician's knowledge in transfusion medicine. Transfus Med. 2002; 12(2) 125-8.

8. Murphy EL, McFarland W, Lefrère J. Teaching transfusion medicine research methods in the developing world. Transfusion. 2009; 49(8) 1532-4.

9. Silva $\mathrm{KFN}$, Soares $\mathrm{S}$, Iwamoto $\mathrm{HH}$. A prática transfusional e a formação dos profissionais de saúde. Rev Bras Hematol Hemoter. 2009; 31(6) 421-6.

10. Peres CM, Andrade AS, Garcia SB. Atividades Extracurriculares: Multiplicidade e Diferenciação Necessárias ao Currículo. Rev Bras Edu Méd. 2007; 31(2); 147-55.

11. Grosseman S, Stoll C. O Ensino-aprendizagem da Relação Médico-paciente: Estudo de Caso com Estudantes do Último Semestre do Curso de Medicina. Rev Bras Educ Méd. 2008; 32 (3) 301-8.

12. Assunção LF, Melo GCMP, Maciel D. Relação Médico-paciente Permeando o Currículo na Ótica do Estudante. Rev Bras Educ Méd. 2008; 32(3) 383-9.

13. Peres CM, Andrade ADS, Garcia SB. Atividades extracurriculares: multiplicidade e diferenciação necessárias ao currículo. Rev Bras Edu Méd 2007; 31(3) 203-11.

14. Ribeiro FMM, Amaral SFC. Medicina centrada no paciente e ensino médico: a importância do cuidado com a pessoa e o poder médico. Rev Bras Edu Méd. 2008; 32(1) 90-97.

15. Trindade LMDF, Jésia M. $O$ aluno de medicina e estratégias de enfrentamento no atendimento ao paciente. Rev Bras Edu Méd. 2013; 37 (2),167-177.

16. Garcia MAA, Pinto ATBC, Odoni APDC, Longhi BS, Machado LI, Linek M, Costa NA. A interdisciplinaridade necessária à educação médica. Revista Bras Edu Méd. 2007; 31(2) 147-55.

17. Brasil. Ministério da Saúde. Secretaria de Gestão do Trabalho e da Educação na Saúde. Departamento de Gestão da Educação na Saúde. A educação permanente entra na roda: polos de educação permanente em saúde: conceitos e caminhos a percorrer. $2^{\text {a }}$. ed. Brasília, DF; 2005.

18. Flausino G de F, Nunes FF, Cioffi JGM, Proietti AB de FC. Teaching transfusion medicine: current situation and proposals for proper medical training. Rev Bras Hematol Hemoter. 2015; 37(1) 58-62.

19. Salpeter SR, Buckley JS, Chatterjee S. Impact of more restrictive blood transfusion strategies on clinical outcomes: a meta-analysis and systematic review. Am J Med. 2014; 127(2)124-31. 